\title{
Corporate Governance and Business Capabilities: Strategic Factors for Corporate Social Responsibility Reporting
}

\author{
Faizah Darus, Noor Hidayah Mat Isa, Haslinda Yusoff and \\ Roshayani Arshad
}

Accounting Research Institute \& Faculty of Accountancy, Universiti Teknologi, Mara, Malaysia

Correspondence should be addressed to: Faizah Darus; faiza634@salam.uitm.edu.my

Received date: 6 October 2014; Accepted date: 23 March 2015; Published date: 2 September 2015

Copyright (C) 2015. Faizah Darus, Noor Hidayah Mat Isa, Haslinda Yusoff and Roshayani Arshad . Distributed under Creative Commons CC-BY 4.0

\begin{abstract}
Corporate Social Responsibility (CSR) is a topical business issue in the current accountability-integrity age. This paper aims to examine and interpret the possible link between corporate governance, business capabilities and CSR reporting practices. Specifically, agency and resource-based theories were used as the underpinning theoretical perspectives in understanding the link between the corporate governance mechanism and their business capabilities with CSR reporting. Using a content analysis of the annual and sustainability reports, the relevant data were gathered from 100 leading companies listed on Bursa Malaysia. The results of the study revealed that corporate governance mechanism, in particular, board size has a significant potential to induce company/'agents' to engage in CSR reporting practices hence reducing agency costs. In the context of business capabilities, human resources in the form of commitment of top leadership to CSR initiatives was found to be a strategic factor in enhancing the CSR information disclosed. The companies' engagement with stakeholders through social dialogues also assisted companies in reducing information asymmetry resulting in the maximization of shareholders' interest.
\end{abstract}

Keywords: Corporate Social Responsibility, Disclosure, Governance, Agency Theory, Resource-based Theory, Malaysia.

\section{Introduction}

In the past, firms were presumed to have met their responsibilities if they operated within the rule of law, generate profits and provided employment for members of society (Epstein et al, 1976). However, in today's environment firms are expected to be more socially responsible and to commit to corporate social responsibility (CSR) activities. Bursa Malaysia (2012) defines CSR as:

"Open and transparent business practices that are based on ethical values and respect for the community, employees, the environment and shareholders. It is 
designed to deliver sustainable value to society at large."

Based on the economic perspectives, apart from functioning as a fundamental activity to a company, CSR also acts as a prime factor to gain competitive advantage (Bayoud and Kavanagh, 2012; Ramdhony and Oogarah-Hanuman, 2012). Effective implementation of CSR among companies can be ensured through the active role of corporate governance. Previous studies have found that strong corporate governance mechanism increased the level of corporate disclosure (e.g. Lakhal, 2005; Cheng and Courtenay, 2006; Said et al, 2009; Esa and Ghazali, 2012); hence, the role of top management in a company's CSR reporting is rather crucial. The availability of resources within a business such as profits will also facilitate a company's CSR initiatives including the wise utilization of resources towards meaningful social development activities (e.g. Waddock and Graves, 1997). These literatures suggest that a well established corporate governance framework has the potentials to foster and stimulate CSR initiatives (see Bhimani and Soonawalla, 2005); as it provides a sturdy foundation for business-CSR related engagements. Hence, this study aims to examine and understand the influence of corporate governance and business capabilities on CSR reporting practices in a developing economy's setting, particularly in Malaysia.

The remainder of this paper is organised as follows. Section 2 discusses the literature review and hypotheses generation. Section 3 discusses the research methodology. The research findings are reviewed in Section 4. The final section highlights the conclusion and implications of the results.

\section{Literature Review and Hypotheses Generation}

\section{Corporate Governance and CSR disclosure}

In this study the agency theory is used to underpin the theoretical relationship between governance and CSR initiatives. According to Jensen and Meckling (1976), agency conflict exists between managers and shareholders because of the disjointing of ownership and control. Due to the separation of ownership, managers (as agents) are entrusted with the responsibility to manage business capabilities to ensure engagement in CSR initiatives. A structured corporate governance mechanism will facilitate the strategic fit between managers' CSR initiatives with the interest of the principal (shareholders) thus, reducing agency costs. The disclosure of CSR information can minimise the agency gap as shareholders are able to gather all CSR related initiatives undertaken by the companies which in turn will reduce agency problem and alleviate information asymmetry between shareholders and managers. This is because under the agency theory, agents are assumed as opportunist and will seek to maximize their interests rather than the shareholders' (Sacconi, 2012).

The effect of agency theory on managers' CSR decisions towards CSR activities in this study is examined by independent variables related to the various elements of corporate governance comprising of board structure (board size, the presence of independent directors on board and the presence of female directors on board) and the ownership structure of the companies. To a certain extent, prevailing literature discovers evidences relating to the influence of corporate governance mechanisms on managers' CSR related decisions (e.g. Eng and Mak, 2003; Barako et al, 2006; Buniamin, et al., 2011; Esa and Ghazali, 2012). Prior literature also reveals that the various elements of corporate ownership structures have an influence on managers' disclosure decisions in companies' annual reports (e.g. Chen and Jaggi, 2000; Haniffa and Cooke, 2002; Chau and Gray, 2002; Ho and Wong, 2001; Darus et al. 2009; Said et al, 2009).

A study by Esa and Ghazali (2012), which examines the extent of CSR disclosure in Malaysian Government Linked Companies (GLCs), establishes that board size is significant in influencing the extent of CSR disclosure. This is consistent with the findings by Buniamin et al. (2011) who 
found that the board size plays an important factor and influences the level of environmental disclosure in Malaysia. However, there are mixed findings with regards to the presence of independent directors (Eng and Mak, 2003; Barako et al, 2006; Esa and Ghazali, 2012) and female directors (Adams and Ferreira, 2009; Bear et al, 2010) with CSR disclosure. Due to the mixed findings, it is of the interest of this study to investigate the influence of independent directors and female directors on CSR disclosure.

In terms of ownership structure, a study by Mohd Nasir and Abdullah (2004) discovers that director's shareholding levels have a significant and positive association with the level of voluntary disclosures. However, Guan Yeik (2006) and Eng and Mak (2003) who examine the relationship between director ownership and CSR provides different results. Their findings indicate that director ownership is significantly negatively related to CSR disclosure. Haniffa and Cooke (2002) and Darus et al (2009) find that companies with more family members on board tend to disclose less CSR activities. Eng and Mak (2003), on the other hand, found that government ownership is positively associated with the extent of voluntary disclosure (also Said et al, 2009). This finding is also consistent with Darus et al (2009) who argue that government owned companies disclose more CSR information, as agency problems in these companies are relatively higher than privately-owned companies.

Based on these arguments, the following hypotheses were developed in the context of corporate governance mechanism:

H1: There is a positive relationship between board size and CSR disclosure.

H2: There is a positive relationship between the proportion of independent directors on board and CSR disclosure.

H3: There is a negative relationship between the percentage of director ownership and CSR disclosure.

H4: There is a positive relationship between female directors on board and CSR disclosure.
H5: There is a negative relationship between family members on board and CSR disclosure

H6: There is a positive relationship between the percentage of government ownership and CSR disclosure.

\section{Business Capabilities and CSR Disclosure}

Prior literature suggests that business capabilities in the form of internal resources such as assets or capabilities that are owned and controlled by companies are useful in implementing strategies and accomplishing objectives (e.g. Collis, 1994; Castelo and Lima, 2006). Resource-based theory posits that firm resources is one of the important factors that contribute towards firms' sustainable competitive advantage and provides superior firm performance. Profits and investments have been found to a certain extent to influence CSR initiatives (Bowman and Haire, 1976; Waddock and Graves, 1997). However, Belkaoui and Karpick (1989) found a negative relationship between return on asset and CSR disclosure. Meanwhile, Cowen et al (1987) and Hackston and Milne (1996) found no association between profitability and CSR disclosure. The support and commitment of human resources such as from top leadership is essential for the enhancement of CSR initiatives and are paramount for superior CSR reporting (Maclean and Rebernak, 2007). In addition, the international experience of top leaders will also provide an added advantage for companies in dealing with social and environmental issues and will facilitate the development of CSR strategies and policies. This is because the centrality of CSR initiatives to organization's mission and objectives can affect the ability of the CSR programmes to create value to the organization (Oswald et al, 1994; Tsai and Ghoshal, 1998). Furthermore, organizations that possess good relationship with their stakeholders will encourage socially responsible behaviours (Heugens et al, 2002).

Based on these arguments, the following hypotheses were formulated to examine the relationship between business capabilities and CSR disclosure: 
H7: There is a positive relationship between company's profit and CSR disclosure

H8a: There is a positive relationship between top leadership commitment and CSR disclosure.

H8b: There is a positive relationship between top leadership international experience and CSR disclosure.

H9a: There is a positive relationship between shared vision and CSR disclosure.

H9b: There is a positive relationship between stakeholder engagement and CSR disclosure.

\section{Research Methodology}

The sample consisted of the 100 leading companies (based on market capitalization) listed on the Main Board of Bursa Malaysia for the year 2011. Using content analysis approach, the data for this study were gathered from both company annual and sustainability reports. Such an approach has been chosen based on the argument that the volume of disclosure signifies the relative importance of information disclosed (Krippendorf, 1980; Gray et al, 1995; Neu et al, 1998; Yusoff et al, 2006). This study used the formorientated analysis, in which the CSR disclosures were collected via the word measurement approach (also, Zeghal and Ahmed, 1990; Deegan and Gordon, 1996; Smith and Taffler, 2000).

The statistical analysis conducted in this study includes the use of multiple linear regression models in order to analyze the relationship between the CSR disclosure and the independent variables. The following regression model is developed to test $\mathrm{H} 1$ to $\mathrm{H} 9$.

CSRDQ $=\beta_{0}$ Constant $+\beta_{1}$ NUM $+\beta_{2}$ IND + $\beta_{3}$ DOW $+\beta_{4}$ FEMALE $+\beta_{5}$ FAM $+\beta_{6} \mathrm{GOV}+$ $\beta_{7}$ PROFIT $+\beta_{8}$ COM $+\beta_{9}$ INTER $+\beta_{10}$ SVIS + $\beta_{11} \mathrm{SENG}+\beta_{12} \mathrm{SIZE}+\epsilon$

Where:

CSRDQ $=\quad$ Word count of the CSR information disclosed.

NUM $=$ Total number of directors on Board.
IND $=$ Proportion of the number of independent directors against the total number of directors on board. A score of 1 is awarded if the proportion is less than 33 percent and 0 if it is otherwise.

DOW $=$ Percentage of common shares held by the CEO or the Managing Director is proportioned over the total number of common shares issued. A score of 1 is awarded for holding of less than 5\% percent and 0 if it is otherwise.

FEMALE $=$ Number of female directors on Board.

FAM = Percentage of family members on Board to total number of directors on board.

GOV $=$ Percentage of shares owned by government institutions listed in top thirty shareholdings to total number of shares issued.

PROFIT = $\quad$ Return on equity.

COM = Top leadership commitment; score of ' 1 ' if the top leadership shows commitment and initiative towards CSR and ' 0 ' if otherwise.

INTER $=$ Top $\quad$ leadership international experience; score of ' 1 ' if top leadership possesses international experience and " 0 " if otherwise.

SVIS = Shared vision; score of ' 1 ' if vision and mission statement is related to CSR and "0" if otherwise.

SENG = Stakeholder engagement; if they consider the interests of stakeholders in CSR decision by creating a formal social dialogue and ' 0 ' if otherwise.

$$
\begin{aligned}
& \text { SIZE }=\quad \text { Total assets. } \\
& €=\text { Error term } \\
& \text { Research Findings }
\end{aligned}
$$

\section{Descriptive Statistics}

Table 1 presents the quantity of CSR disclosure (CSRDQ) by industries. The Trading and Service industry showed the 
highest maximum disclosure of 32,123 words, suggesting that companies in this industry have provided more CSR information in their annual reports. However, surprisingly the Plantation industry has reported the lowest disclosure with a minimum score of 0 , indicating that there are companies in the plantation industry that do not undertake any CSR activities resulting in non-disclosure. The plantation industry, which is classified as one of the sensitive industries, is highly expected to be more proactive in their CSR activities especially in terms of the environmental dimension. The Trading and Service industry also recorded the highest mean score among all industries (5119.03 words). This suggests that on average, companies in this industry have more CSR disclosure in their annual and sustainability reports as compared to other industries in Malaysia. This could be due to the fact that companies in this industry are more closely related to the sale and provision of services to customers and have taken the initiatives to disclose more CSR information in order to appeal to their customers.

Table 1: Descriptive analysis of CSR disclosure by industry

\begin{tabular}{|l|c|c|c|c|c|}
\hline INDUSTRY & N & Minimum & Maximum & Mean & Std. Deviation \\
\hline Trading and Service & 34 & 744 & 32123 & 5119.03 & 5971.22 \\
\hline Finance & 14 & 508 & 19094 & 4747.93 & 5411.10 \\
\hline Industrial Product & 9 & 736 & 12182 & 3806.11 & 3631.34 \\
\hline Plantation & 11 & 0 & 6740 & 3482.27 & 2474.45 \\
\hline Infrastructure (IPC) & 5 & 276 & 14037 & 5049.00 & 5738.58 \\
\hline Consumer Product & 14 & 545 & 11724 & 3374.50 & 2991.33 \\
\hline Property & 7 & 221 & 4375 & 2049.57 & 1541.72 \\
\hline Construction & 4 & 1129 & 8549 & 4442.00 & 3099.83 \\
\hline Real Estate Investment Trust & 2 & 1727 & 2868 & 2297.50 & 806.81 \\
\hline
\end{tabular}

Table 2 presents the Pearson Correlation Coefficient between the dependent, independent and control variables for the study.

Table 2: Pearson correlation matrix for the dependent, independent and control variables

\begin{tabular}{|c|c|c|c|c|c|c|c|c|c|c|c|c|c|}
\hline & NUM & IND & Dow & FEMALE & FAM & GOV & COM & INTER & SVIS & SENG & $\begin{array}{c}\text { PROFI } \\
T\end{array}$ & SIZE & $\begin{array}{l}\text { CSR } \\
\mathrm{nn}\end{array}$ \\
\hline NUM & 1 & & & & & & & & & & & & \\
\hline IND & $.406^{* *}$ & 1 & & & & & & & & & & & \\
\hline DOW & -.140 & $-.200^{*}$ & 1 & & & & & & & & & & \\
\hline FEMALE & $.399^{* *}$ & .160 & .114 & 1 & & & & & & & & & \\
\hline FAM & $.236^{*}$ & $.266^{* *}$ & $-.284^{* *}$ & .101 & 1 & & & & & & & & \\
\hline GOV & .142 & $.218^{*}$ & .102 & $.228^{*}$ & $-.302^{* *}$ & 1 & & & & & & & \\
\hline COM & -.058 & -.062 & .083 & $-.219^{*}$ & -.050 & .019 & 1 & & & & & & \\
\hline INTER & $.209^{*}$ & -.017 & -.116 & -.021 & -.067 & $-.247^{*}$ & .107 & 1 & & & & & \\
\hline SVIS & .034 & -.079 & .086 & .041 & $-.202^{*}$ & .129 & -.022 & .113 & 1 & & & & \\
\hline SENG & -.063 & -.130 & .170 & .129 & $-.352^{* *}$ & $.285^{* *}$ & $.235^{*}$ & .022 & .137 & 1 & & & \\
\hline PROFIT & -.150 & -.018 & .050 & -.185 & .014 & $-.265^{* *}$ & $.213^{*}$ & .030 & -.091 & .089 & 1 & & \\
\hline SIZE & .115 & -.064 & .006 & .126 & .032 & -.041 & -.116 & .048 & -.087 & -.064 & .010 & 1 & \\
\hline CSRDQ & $.240^{*}$ & .076 & -.130 & -.045 & -.042 & .168 & $.257^{* *}$ & .122 & .081 & $.413^{* *}$ & -.051 & .026 & 1 \\
\hline
\end{tabular}

**. Correlation is significant at the 0.01 level (2-tailed), *. Correlation is significant at the 0.05 level (2-tailed). 
The results from the correlation analysis indicate that all the correlation coefficients between the independent variables are less than 0.9; hence, no multicollinearity exists among the variables tested in this study.
The results also indicate that board size (NUM), top leadership commitment (COM) and stakeholder engagement (SENG) are positively correlated with CSR disclosure (CSRDQ) at $1 \%$ and $5 \%$, respectively.

Table 3: Multiple regression results for factors affecting CSR disclosure (CSRDQ)

Dependent Variable : CSRDQ (Word Count)
R Square $=0.349$, Adjusted $\mathrm{R}^{2}=0.259, \mathrm{~F}=3.883$, Sig. $=0.000$

\begin{tabular}{|llll|}
\hline Variables & Beta & $\mathbf{t}$ & Sig. \\
\hline (Constant) & & -.947 & .346 \\
\hline NUM & .289 & 2.637 & $.010^{* * *}$ \\
\hline IND & .016 & .150 & .881 \\
\hline DOW & -.136 & -1.440 & .153 \\
\hline FEMALE & -.218 & -2.099 & $.039^{* *}$ \\
\hline FAM & .062 & .573 & .568 \\
\hline GOV & .048 & .430 & .668 \\
\hline PROFIT & -.102 & -1.078 & .284 \\
\hline COM & .159 & 1.665 & $.099^{*}$ \\
\hline INTER & .026 & .269 & .789 \\
\hline SVIS & .033 & .367 & .715 \\
\hline SENG & .463 & 4.575 & $.000^{* * *}$ \\
\hline SIZE & .073 & .815 & .417 \\
\hline
\end{tabular}

Coefficient for each variable is shown with $t$ - statistics in parentheses *Significant at $10 \%$ level

**Significant at $5 \%$ level ${ }^{* * *}$ Significant at $1 \%$ level

The results from Table 3 indicates that the F-statistic for the model is 3.883 and is significant $(\mathrm{p}=0.000)$ and the adjusted $\mathrm{R}^{2}$ is 0.259 . This adjusted $\mathrm{R}^{2}$ suggests that $25.9 \%$ variation in CSR disclosure could be explained by the 12 variables specified in the model.

The results reveal that the total number of directors on the board (NUM), female directors (FEMALE), top leadership commitment (COM) and stakeholder engagement (SENG) are significant. However, for FEMALE, even though the results are significant it is not in the hypothesized direction. The results revealed that board size, commitment of top leadership and stakeholder engagement influence the CSR information disclosed in companies' annual and sustainability reports. Such a finding implies that the higher the number of directors on the board, the more committed the top leadership towards CSR initiatives and the more the company engaged with its stakeholders, the higher the level of CSR disclosure. Firms with larger boards, strong top leadership commitment and are actively involved in stakeholder engagement tend to engage in CSR activities and disclose more CSR related information. This is because by having a large board, they are able to exchange ideas and opinions regarding the CSR activities that are to be undertaken by the company. Furthermore, by having top leadership that are committed towards CSR implementation has successfully encouraged companies to be actively involved in CSR practices, which in turn promotes CSR disclosure. Formal dialogues with stakeholders also improved CSR information disclosed as they are better informed of the type and amount of information required by the stakeholders. Essentially, they will be inclined to disclose 
more, in order to build a good relationship with their stakeholders. Therefore, H1, H8a and $\mathrm{H} 9 \mathrm{~b}$ are accepted. Meanwhile the other variables, board independence (IND), director ownership (DOW), family ownership (FAM), government ownership (GOV), profits (PROFIT), top leadership international experience (INTER), shared vision (SVIS) and SIZE have displayed insignificant results. Therefore, H2, H3, H4, H5, H6, H7, H8b, H9a are rejected.

\section{Conclusion}

Overall, the agency and resource-based theories have been found as useful in understanding the relationship between corporate governance and business capabilities with CSR reporting among companies in Malaysia. Descriptive analysis has revealed that the Trading and Service industry as the top reporter for CSR information. Unexpectedly, the Plantation industry, which is often classified as one of the sensitive industries, was not proactive in the reporting CSR information to reduce agency costs. The regression analyses results revealed that larger board size tends to induce company/'agents' to engage in CSR initiatives as well as to disclose CSR information hence reducing agency costs and maximizing the welfare of shareholders/'principals'. This study also found that business capabilities in the form of commitment of top leadership have significant influence on CSR initiatives, particularly in enhancing CSR information disclosed. Additionally, formal social dialogues with stakeholders will also facilitate in reducing information asymmetry hence leading to the maximization of shareholders' interest. The findings offer insights about the strategic business factors that resulted in greater CSR reporting amongst corporate citizens.

\section{Acknowledgements}

The authors would like to express their gratitude to the Ministry of Education, Malaysia and Universiti Teknologi MARA for funding and facilitating this research project.

\section{References}

1. Adams, R. B. and Ferreira, D. (2009), 'Women in the Boardroom and their Impact on Governance and Performance',Journal of Financial Economics, 94(2), 291-309.

2. Barako, D. G., Hancock, P. and Izyan, H. Y. (2006), 'Factors Influencing Voluntary Corporate Disclosures by Kenyan Companies', Corporate Governance, 14(2), 107-125.

3. Bayoud, N. S. and Kavanagh, M. (2012), 'The Importance and Benefit of Corporate Social Responsibility Disclosure in the Libyan Context: Evidence from Managers', Global Conference on Business and Finance Proceedings, 7(1), 84-95.

4. Bear, S., Rahman, N. and Post, C. (2010), 'The Impact of Board Diversity and Gender Composition on Corporate Social Responsibility and Firm Reputation', Journal of Business Ethics, 97, 207-221.

5. Belkaoui, A. and Karpick, P. G. (1989), 'Determinants of the Corporate Decision to Disclose Social Information, Accounting, Auditing and Accountability Journal, 2(1), 36-51.

6. Bhimani, A. and Soonawalla, K. (2005), 'From Conformance to Performance: The Corporate Responsibilities Continuum'. Journal of Accounting and Public Policy, 24(3), 165-254.

7. Bowman, E. H. and Haire, M. (1976), 'Social Impact Disclosure and Corporate Annual Reports, Accounting, Organizations and Society, 1(1), 11-21.

8. Buniamin, S., Alrazi, B., Johari, N. H. and Rahman, N. R. A. (2011), 'Corporate government practices and environmental reporting of companies in Malaysia: finding possibilities of doubles thumbs up', Jurnal Pengurusan, 32, 55-71.

9. Bursa Malaysia (2012). Bursa Malaysia, Sustainability. Retrieved 21 August 2012, from Bursa Malaysia website at http://www.bursamalaysia.com/market/li 
sted-

companies/sustainability/introduction/sus tainability-trends-in-malaysia/

10. Castelo, M. and Lima, L. (2006), 'Corporate Social Responsibility and Resource-Based Perspectives', Journal of Business Ethics, 69, 111-132.

11. Chau, G. K. and Gray, S. J. (2002), 'Ownership Sructure and Corporate Voluntary Disclosure in Hong Kong and Singapore', The International Journal of Accounting, 37, 247-265.

12. Chen and Jaggi, B. (2000), 'Association between Independent Non-Executive Directors, Family Control and Financial Disclosures in Hong Kong', Journal of Accounting and Public Policy, 19, 285-310.

13. Cheng, E. C. M. and Courtenay, S. M. (2006), 'Board Composition, Regulatory Regime and Voluntary Disclosure', The International Journal of Accounting, 41, 262-289.

14. Collis, D. J. (1994) 'Research Note: How Valuable Are Organizational Capabilities?', Strategic Management Journal, 15, 143-152.

15. Cowen, S. S., Fererri, L. B. and Parker, L. D. (1987), 'The Impact of Corporate Characteristics on Social Responsibility Disclosures: A Typology and FrequencyBased Analysis', Accounting, Organizations and Society, 12(2), 111-122.

16. Darus, F., Arshad, R., Othman, S., Jusoff, K. (2009), 'Influence of Institutional Pressure and Ownership Structure on Corporate Social Responsibility Disclosure', Interdisciplinary Journal of Contemporary Research In Business, 1(5), 123-150.

17. Deegan, C. and Gordon, B. (1996), 'A Study of the Environmental Disclosure Practices of Australian Corporations', Accounting and Business Research, 26(3), 187-199.

18. Eng, L. L. and Mak, Y. T. (2003), orporate Governance and Voluntary Disclosure Jounal of Accounting and Public Policy, 22(4), 325-345.
19. Epstein, M. J., Flamholtz, E. and McDonough, J. J. (1976), 'Corporate Social Accounting in The United States of America: State of the Art and Future Prospects', Accounting, Organizations and Society, 1, 23-42.

20. Esa, E. and Ghazali, N. A. M. (2012), 'Corporate Social Responsibility and Corporate Governance in Malaysian Government-Linked Companies', Corporate Governance, 12(3), 292-305.

21. Gray, R., Kouhy, R. and Lavers, S. (1995), 'Corporate Social and Environmental Reporting: A Review of the Literature and a Longitudinal Study of UK Disclosure', Accounting, Auditing \& Accountability Journal, 8(2), 47-77.

22. Guan Yeik, T. (2006), 'The Relationship Between Board of Directors and Corporate Social Responsibility: Study on Malaysian Public Listed Companies', Master's in Accounting, Universiti Sains Malaysia, Penang, Unpublished Thesis.

23. Hackston, D. and J, M. M. (1996), 'Some Determinants of Social and Environmental Disclosures in New Zealand Companies'. Accounting, Auditing and Accountability Journal, 9(1), 77-108.

24. Haniffa, R. and Cooke, T. (2002), 'Culture, Corporate Governance and Disclosure in Malaysian Corporations', ABACUS, 38(3), 317-349.

25. Heugens, P. P. M. A. R., Bosch, F. A. J. v. d. and Riel, C. B. M. v. (2002), 'Stakeholder Integration: Building Mutually Enforcing Relationships', Business and Society, 41(1), 36-60.

26. Jensen, C. M. and Meckling, W. H. (1976), 'Theory of The Firm: Managerial Behaviour, Agency Costs and Ownership Structure', Journal of Financial Economics, $3,305-360$

27. Krippendorff, K. (1980) Content Analysis: An Introduction to its Methodology. Sage, London.

28. Lakhal, F. (2005) 'Voluntary Earnings Disclosures and Corporate Governance: 
Evidence from France', Review of Accounting and Finance, 4(3), 64-85.

29. MacLean, R. and Rebernak, K. (2007), 'Closing the Credibility Gap: The Challenges of Corporate Responsibility Reporting', Environmental Quality Management, 16(4), 1-6.

30. Mohd Nasir, N. A. and Abdullah, S. N. (2004), 'Voluntary Disclosure and Corporate Governance Among Financially Distresses firms in Malaysia', Financial Reporting, Regulation and Governance, 3(1).

31. Neu, D., Warsame, H. and Pedwell, K. (1998), 'Managing Public Impressions: Environmental Disclosures in Annual Reports'. Accounting, Organizations and Society, 23(3), 265-282.

32. Oswald, S. L., Mossholder, K. W. and Harris, S. G. (1994), 'Vision Salience and Strategic Involvement: Implications for Psychological Attachment to Organization and Job', Strategic Management Journal, 15(6), 477-489.

33. Ramdhony, D. and Oogarah-Hanuman, V. (2012), 'Improving CSR Reporting in Mauritius- Accountants' Perspectives', World Journal of Social Sciences, 2(4), 195207.

34. Sacconi, L. (2012) 'Corporate Social Responsibility and Corporate Governance'. Retrieved 1 September 2013 from http://extranet.isnie.org/uploads/isnie201 2/sacconi.pdf.

35. Said, R., Zainuddin, Y. H. and Haron, H. (2009), 'The Relationship Between Corporate Social Responsibility Disclosure and Corporate Governance Characteristics in Malaysian Public Listed Companies', Social Responsibility Journal, 5(2), 212-226.

36. Smith, M. and Taffler, R. J. (2000), "The Chairman's Statement - A Content Analysis of Discretionary Narrative Disclosures', Accounting, Auditing \& Accountability Journal, 13(5), 624-647.

37. Tsai, W. and Ghoshal, S. (1998), 'Social Capital and Value Creation: The Role of Intrafirm Networks', Academy of Management Journal, 41(4), 464-476.

38. Waddock, S. A. and Graves, S. B. (1997), 'The Corporate Social PerformanceFinancial Performance Link', Strategic Management Journal, 18(4), 303-319.

39. Yusoff, H., Lehman, G. and Mohd Nasir, N. (2006), 'Environmental Engagements through the Lens of Environmental Disclosures: A Malaysian Story', Asian Review of Accounting, 14(1/2), 122-148.

40. Zeghal, D. and Ahmed, S. (1990), 'Comparison of Social Responsibility Information Disclosure Media Used by Canadian Firms', Accounting, Auditing \& Accountability Journal, 3(1), 38-53. 